\title{
Profile of Catechins, Caffeine and Antioxidant Activities of Green Tea of Assam
}

\author{
Madhusmita Neog and Priyanka Das* \\ Department of Biochemistry and Agricultural Chemistry, Assam Agricultural University, \\ Jorhat, Assam, India \\ *Corresponding author
}

\section{A B S T R A C T}

Key w o r d s
Green tea, Catechin,
Caffeine,
Antioxidant, DPPH
scavenging

Considering importance of green tea in daily life, together with increase in green tea manufactured traditionally in Assam, a study was conducted to compare the quality of green tea manufactured, both commercially and traditionally during different flushes. The total catechin ranged from $13.46 \%$ to $20.80 \%$. The caffeine content in chloroform extract and in acidified hot water extract ranged from 1.80 $\%$ to $3.21 \%$ and from $1.60 \%$ to $3.39 \%$, respectively. The $\mathrm{IC}_{50}$ values responsible for the fifty percent DPPH scavenging activity of green tea ranged from $14.31 \mathrm{mg}$ to $16.66 \mathrm{mg}$. The study reveals that the green tea processed through traditional method involving boiling and drying is better than commercial one in respect to the content of higher total catechin, lower caffeine and lower $\mathrm{IC}_{50}$ value for $\mathrm{DPPH}$ scavenging.

\section{Introduction}

Green tea, called non-fermented tea with more subtle, delicate flavour, and far less caffeine content than fermented tea, is nutritionally beneficial because the nonfermented leaves retain a higher concentration of natural vitamins and polyphenols than the fermented counterparts (Chen et al., 2008; Neog et al., 2018; Neog et al., 2020). Green tea is rich in chemicals called catechins, which are a form of flavanol monomers, a type of flavonoid. The catechins include epicatechin (EC), epigallocatechin (EGC), epicatechin-3- gallate (ECG), and epigallocatechin-3- gallate (EGCG). In addition, green tea also contains a small amount of vitamin $\mathrm{C}$, caffeine, theanine, and phenolic acids such as gallic acid (Farhosh et al., 2007).

Green tea components possess antioxidants, antimutagenic, and anticarcinogenic activity (Leenen et al., 2000). This beneficial effect has been attributed to the presence of high amounts of polyphenols which are potent antioxidants. In particular, green tea may lower blood pressure and thus reduce the risk of stroke and coronary heart disease (Tsuneki et al., 2004; Williamson et al., 2005) Green 
tea extracts containing catechins are known to have strong antioxidant properties in vitro (Higdon and Frei 2005). The catechins are able to protect biological molecules such as lipids, and proteins against the adverse effects of reactive oxygen and reactive nitrogen species (Leung et al., 2001).

The antioxidant activity of tea flavonoids is often suggested as a mechanism of action for the health benefits associated with tea drinking (Williams et al., 1996).Green tea is sold as fresh or dried unfermented leaves. A highly prized collection comes from plucking the very early shoots of green tea, which are almost white in color and much sought after (Rahman et al., 2013; Chaudhury et al., 2010).Tea flush is the term for these young shoots, consisting of a terminal bud and two adjacent leaves. In green tea production, the young leaves are not allowed to oxidize (Hara et al., 1995; Khalid et al., 2016; Caffin et al., 2005). Instead, they are heated, which inactivates the enzymes (i.e. polyphenol oxidase), thus preserving the polyphenols.

The fresh green leaves are steamed or boiled, rolled, and finally dried in a drier or pan-fired. Tender tea leaves and buds are manually plucked by skilled women workers from the tea plants after a fixed duration. Ideal plucking period for making a good quality green tea is 5-8 days (Rahman et al., 2013; Lin and Chi 1995). The composition in fresh tea leaves varies with the tea clones (Caffin $e t$ al., 2005; Hara et al., 1995). In Assam, among Tocklai vegetative (TV) clones, TV 1, TV 9, TV 19, TV 23 and TV 26 are very popular among tea growers. TV 23 was found to be one of the most preferred clones by the present day tea growers of North-East India due to its highly drought tolerant ability, high yield and average quality (Barua 1964).

Documentation of processing methods (Neog et al., 2018) and some of the biochemical qualities of green tea manufactured by increasingly growing small tea growers of Assam (Neog et al., 2020) are recently reported by the present authors. The aim of the present investigation was to compare different methods of green tea processing and identify the best traditional method together with the plucking season at which the important nutritional and sensory parameters are at the peak.

\section{Materials and Methods}

Commercial green tea samples made from Tocklai vegetative 23 (TV 23) clone were collected from Labonya Tea Industry, District Sonitpur, Assam, India. The traditionally manufactured green tea samples made from the same clone were collected from a small tea grower Shri Basanta Duwara of Geleki, Sivsagar, Assam, India. The green tea samples were collected at four different plucking seasons; first flush (late March to April), second flush (end of May to June), third or rainy flush (July to September) and forth flush or autumn flush (October to mid November).

Four types of traditionally manufactured green tea and one type of commercially manufactured green tea were used for the present study, as mentioned below.

Commercially manufactured (roasted. mechanically rolled and dried in mechanical drier)

Traditionally manufactured (boiled, manualy rolled and dried in a tray drier)

Traditionally manufactured (boiled, manualy rolled and pan fired)

Traditionally manufactured (steamed, manualy rolled and dried in a tray drier) 
Traditionally manufactured (steamed, manualy rolled and pan fired)

Considering toxicity of chloroform, the acidified hot water extraction of caffeine was also included for comparison of both the methods. The caffeine content of green tea was estimated by two methods; first in chloroform extract as described by Ullah et al., (1987) and then in acidified hot water extract as described by Wanyike et al., (2010). For chloroform extract, the absorbance of the filtrate was measured using a UV/Visible spectrophotometer at $276 \mathrm{~nm}$. Caffeine percentage was read directly from the standard curve prepared with caffeine (1 to $5 \mathrm{ppm}$ ) and expressed on dry weight basis.

For acidified hot water extract, the absorbance of the filtrate was measured using a UV/Visible spectrophotometer (Spectrascan UV 2600 double beam UV-VIS spectrophotometer, Chemito make) at 274 $\mathrm{nm}$. The concentration of caffeine (\%, dry basis) was calculated with the help of a standard curve prepared using pure caffeine (0-80ppm). Caffeine stock solution (1000 ppm) was prepared by dissolving $100 \mathrm{mg}$ of pure caffeine in $100 \mathrm{ml}$ of distilled water. Caffeine working standard solutions $(0,10$, 20, 40, 60 and $80 \mathrm{ppm}$ ) were prepared by serial dilution of the stock in $25 \mathrm{ml}$ volumetric flasks with addition of $1.0 \mathrm{ml}$ hydrochloric acid before topping to the mark with distilled water.

Catechin content in tea samples was estimated by the method of ISO 145022 (ISO, 2005). $0.2 \mathrm{~g}$ of the accurately weighed powdered material was extracted with $5 \mathrm{ml}$ of $70 \%$ aqueous methanol, refluxed in a water bath, kept at $70^{\circ} \mathrm{C}$ for $10 \mathrm{~min}$. After cooling, the extract was centrifuged at $3000 \mathrm{rpm}$ for 10 min. The supernatant is transferred into a 10 $\mathrm{ml}$ volumetric flask. The process was repeated with another $5 \mathrm{ml}$ extraction solvent. $1 \mathrm{ml}$ of the extract was diluted to 5 times with stabilizing agent prepared from 10\% acetonitrile, $25 \mu \mathrm{g} / \mathrm{ml}$ ascorbic acid and EDTA each. The estimation of individual catechins were carried out with a High Performance Liquid Chromatography (Dionex UHPLC system, fitted UV-visible detector). $10 \mu \mathrm{l}$ of the dilute extract was injected into a phenomenox Luna 5 micron phenyl hexyl column $(250 \mathrm{~mm} \times 4.5 \mathrm{~mm})$. The column temperature was kept at $25^{0} \mathrm{C}$ using a column oven.

The mobile phase, solvent $A$ was $2 \%$ acetic acid, 9\% acetonitrile and solvent B was $80 \%$ acetonitrile. The program for elution was $100 \%$ solvent A for initial 10 min followed by gradient to $37 \% \mathrm{~B}$ over a period of $15 \mathrm{~min}$ and another $10 \mathrm{~min}$ with the same condition. The flow rate was $1 \mathrm{ml} / \mathrm{min}$. The UV/VIS detector was set at $276 \mathrm{~nm}$.

Antioxidant activity was measured according to Molynux et al., 2004 using DPPH (2, 2 diphenyl-1-picrylhydrazyl) reagent. Free radical scavenging ability of DPPH was determined on methanolic extracts of green tea dried samples. $1 \mathrm{~g}$ of dried sample powder was extracted in $10 \mathrm{ml}$ methanol, centrifuged at $10000 \mathrm{rpm}$ for 20 minutes and the supernatant was used for assay, after making up volume to $10 \mathrm{ml}$ by methanol. To $25 \mu \mathrm{l}-$ $750 \mu 1$ of methanolic sample extract, methanol was added to make up the volume to $750 \mu 1$.To it $750 \mu 1$ of DPPH reagent $(1 \mathrm{mM}$ in methanol) was added and the mixture was incubated at room temperature at dark for 30 mins. The absorbance was measured using a UV/Visible spectrophotometer (Spectrascan UV 2600 double beam UV-VIS spectrophotometer, Chemito make) at $517 \mathrm{~nm}$ taking methanol as blank. A mixture of equal volume of methanol and DPPH reagent served as control. A decreasing intensity of the purple colouration was taken as increasing scavenging activity. 
The inhibition of DPPH radicals by the sample was calculated as

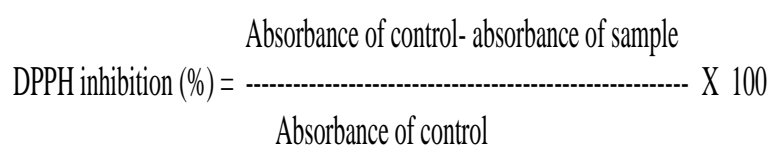

The IC 50 value is expressed in terms of the dry sample (mg) for which 50\% DPPH inhibition was observed. It was calculated from the graph in which the percent DPPH inhibition was plotted against different amount of the samples.

The organoleptic evaluation of the various characteristics that made up a tea liquor, viz, briskness, strength, colour, body, quality and aroma or flavour were assessed using a ten point scale. The said organoleptic evaluation was conducted at the Tocklai Tea Research Institute, Jorhat, Assam by reputed tea taster. The organoleptic evaluation was finally expressed in terms of liquor characteristics.

The analysis of variance (ANOVA) was done for 20 samples (involving 4 different seasonal effect and 5 different manufacturing process) of green tea with three replications in the Factorial Randomized Block Design (RBD). The critical differences were calculated by the formula:

$\mathrm{CD}_{(0.05)}=\mathrm{t}_{0.05}$, error d.f. $\times \mathrm{S} . \mathrm{Ed}$

Where, $\mathrm{S} . \mathrm{Ed}=\sqrt{\frac{2 E M S}{r}}$

The difference of treatments means were tested by Duncan's Multiple Range Test (DMRT) (Duncan, 1955).

\section{Results and Discussion}

The caffeine content of both chloroform extract and acidified hot water extract of green tea of Assam are presented at table 1.
The caffeine content of chloroform extract showed that for commercially made green tea, the highest $(3.21 \%)$ and the lowest $(2.25 \%)$ caffeine content were observed during the fourth and the first flush, respectively. For traditionally processed green tea, the highest $(2.90 \%)$ and the lowest $(1.80 \%)$ caffeine content were observed for green tea of third flush processed through boiling and pan firing and green tea of second flush processed through steaming and pan firing, respectively. The caffeine content of chloroform extract observed in the present study reveals similarity with those reported earlier (Rahman et al., 2013; Zayadi et al., 2016), which were $3.34 \%$ and $3.87 \%$, respectively for chloroform extract of green tea.

The result of caffeine content of acidified hot water extract showed that for commercially made green tea, the highest $(3.39 \%)$ and the lowest $(2.02 \%)$ caffeine content were observed during the fourth and the first flush, respectively. For traditionally processed green tea, the highest $(2.79 \%)$ and the lowest $(1.60 \%)$ caffeine content were observed for green tea processed through steaming and pan firing, for first flush and second flush, respectively.

The present findings on caffeine content was found to be comparable with those reported for acidified hot water extract $(2-5 \%, 1.18$ $3.66 \%$ and $3.83 \%$ ) by Harlan et al., (2015), Astill et al.(2001) and Baruah et al., (2012), respectively.

It was observed that the caffeine content of chloroform extract varied maximum from that of hot water extract by $0.66 \%$ (green tea of second flush processed through steaming and drying) only. Zayadi et al., (2016) also reported almost similar caffeine content for tea extracted both by acidified hot distilled water (3.56\%) and chloroform (3.87\%). Earlier, it was reported that the solubility of 
caffeine in hot water (at $100^{\circ} \mathrm{C}$ ) and chloroform (at $25^{\circ} \mathrm{C}$ ) to be $66.7 \%$ and $18 \%$, respectively (Tarka and Hurst 1998). It was also reported earlier (Lee et al., 2008; Yashin et al., 2011) that acidified hot water was also a good extractor of caffeine. Considering toxicity of chloroform to human health (Lok et al., 2014; Qylo et al., 2016) the acidified hot water extraction of caffeine can be advocated as green reagent.

Detection of higher amount of caffeine (for both the extracts) in commercially prepared green tea samples might be attributed to retention of partly water soluble caffeine due to practice of roasting instead of boiling /steaming followed for traditional methods. We have already reported (Neog et al., 2018; Neog et al., 2020) that the practice of deactivation of oxidizing enzyme viz boiling and steaming followed by hand rolling lead to loss of water soluble components.

The catechin profile of green tea of Assam was presented at Table 2. For commercially made green tea, the highest $(19.09 \%)$ and the lowest $(15.92 \%)$ total catechin content was observed during the fourth and the third flush, respectively. For traditionally made green tea, the highest $(20.80 \%)$ total catechin content was observed for green tea of second flush manufactured though boiling and drying. The lowest total catechin content $(13.46 \%)$ was observed for green tea of third flush processed through steaming and pan firing. The present findings on the catechin content was found to be comparable with those reported by, Astill et al.(2001) and Yashin et al., (2011) who reported the catechin content to be 7.1-20.8\% and $11.19-12.69 \%$, respectively.

For commercially made green tea, the highest $(8.62 \%)$ and the lowest $(6.45 \%)$ EGC content was observed during the fourth and the first flush, respectively. The highest $(9.39 \%)$ EGC content was observed for green tea of second flush manufactured through boiling and drying and the lowest EGC content $(3.51 \%)$ was observed for green tea of third flush processed through steaming and drying.

For commercially made green tea, the highest $(2.23 \%)$ and the lowest $(1.33 \%)$ EC content was observed during the second and the third flush, respectively. The highest (2.33) and the lowest (1.34) EC content was observed for green tea of second flush and third flush, respectively manufactured through same method i.e. steaming and drying.

Table.1 The caffeine content (\%, dry basis) of green tea of Assam

\begin{tabular}{|c|c|c|c|c|c|c|}
\hline Treatments & Commercial & $\begin{array}{l}\text { Boiling and } \\
\text { drying }\end{array}$ & $\begin{array}{l}\text { Boiling } \\
\text { and pan } \\
\text { firing }\end{array}$ & $\begin{array}{l}\text { Steaming } \\
\text { and drying }\end{array}$ & $\begin{array}{l}\text { Steaming } \\
\text { and pan } \\
\text { firing }\end{array}$ & Mean \\
\hline Flush 1 & $2.25(2.02)$ & $1.82(1.93)$ & $2.65(2.27)$ & $2.51(2.52)$ & $2.60(2.79)$ & $2.36(2.31)$ \\
\hline Flush 2 & $2.55(2.34)$ & $2.15(2.50)$ & $1.84(1.90)$ & $2.74(2.08)$ & $1.80(1.60)$ & $2.21(2.08)$ \\
\hline Flush 3 & $3.02(3.00)$ & $2.16(2.55)$ & $2.90(2.74)$ & $2.67(2.24)$ & $2.52(2.60)$ & $2.65(2.62)$ \\
\hline Flush 4 & $3.21(3.39)$ & $2.06(2.39)$ & $1.82(2.07)$ & $2.65(2.24)$ & $2.32(2.45)$ & $2.41(2.51)$ \\
\hline Mean & $2.75(2.34)$ & $2.04(2.24)$ & $2.30(2.27)$ & $2.64(2.45)$ & $2.30(2.36)$ & \\
\hline Factors & \multicolumn{2}{|c|}{ flush } & \multicolumn{2}{|c|}{ Process } & \multicolumn{2}{|c|}{ flush $\mathrm{x}$ process } \\
\hline $\mathrm{CD}_{(0.05)}$ & \multicolumn{2}{|c|}{$\begin{array}{c}0.003 \\
(0.026)\end{array}$} & \multicolumn{2}{|c|}{$\begin{array}{c}0.003 \\
(0.029)\end{array}$} & \multicolumn{2}{|c|}{$\begin{array}{c}0.006 \\
(0.058)\end{array}$} \\
\hline
\end{tabular}

Data in parentheses are the caffeine content in acidified hot water extract 
Table.2 Catechin profile (\%, dry weight) of green tea of Assam

\begin{tabular}{|c|c|c|c|c|c|c|}
\hline & Sample & EGCG & EGC & EC & ECG & Total catechin \\
\hline \multirow{6}{*}{ First flush } & Commercial & 8.87 & 6.45 & 1.98 & 1.56 & 18.86 \\
\hline & $\begin{array}{l}\text { Boiling } \\
\text { drying }\end{array}$ & 9.71 & 5.96 & 1.46 & 1.89 & 19.02 \\
\hline & $\begin{array}{l}\text { Boiling and pan } \\
\text { firing }\end{array}$ & 8.22 & 5.38 & 1.95 & 2.22 & 17.77 \\
\hline & $\begin{array}{l}\text { Steaming and } \\
\text { drying }\end{array}$ & 7.75 & 5.32 & 1.93 & 1.74 & 16.20 \\
\hline & $\begin{array}{l}\text { Steaming and pan } \\
\text { firing }\end{array}$ & 8.34 & 4.45 & 1.66 & 1.11 & 15.56 \\
\hline & $\begin{array}{l}\text { Mean } \\
\text { (First flush) }\end{array}$ & 8.57 & 5.51 & 1.79 & 1.70 & 17.48 \\
\hline \multirow{6}{*}{ Second flush } & Commercial & 6.88 & 7.75 & 2.23 & 1.33 & 18.10 \\
\hline & $\begin{array}{l}\text { Boiling and } \\
\text { drying }\end{array}$ & 6.93 & 9.36 & 2.31 & 1.48 & 20.80 \\
\hline & $\begin{array}{l}\text { Boiling and pan } \\
\text { firing }\end{array}$ & 6.88 & 9.08 & 2.01 & 1.40 & 19.37 \\
\hline & $\begin{array}{l}\text { Steaming and } \\
\text { drying }\end{array}$ & 8.78 & 6.11 & 2.33 & 1.62 & 18.84 \\
\hline & $\begin{array}{l}\text { Steaming and pan } \\
\text { firing }\end{array}$ & 6.71 & 5.13 & 2.24 & 1.46 & 15.04 \\
\hline & $\begin{array}{l}\text { Mean } \\
\text { (second flush) }\end{array}$ & 7.23 & 7.48 & 2.22 & 1.45 & 18.43 \\
\hline \multirow{6}{*}{ Third flush } & Commercial & 6.78 & 6.76 & 1.33 & 1.05 & 15.92 \\
\hline & $\begin{array}{l}\text { Boiling and } \\
\text { drying }\end{array}$ & 6.66 & 8.78 & 1.98 & 1.63 & 19.05 \\
\hline & $\begin{array}{l}\text { Boiling and pan } \\
\text { firing }\end{array}$ & 6.54 & 5.97 & 1.84 & 1.87 & 15.86 \\
\hline & $\begin{array}{l}\text { Steaming and } \\
\text { drying }\end{array}$ & 8.08 & 3.51 & 1.34 & 1.75 & 14.68 \\
\hline & $\begin{array}{l}\text { Steaming and pan } \\
\text { firing }\end{array}$ & 6.03 & 3.84 & 2.23 & 1.36 & 13.46 \\
\hline & $\begin{array}{l}\text { Mean } \\
\text { (third flush) }\end{array}$ & 6.81 & 5.77 & 1.74 & 1.53 & 15.79 \\
\hline \multirow{6}{*}{ Fourth flush } & Commercial & 7.34 & 8.62 & 2.04 & 1.09 & 19.09 \\
\hline & $\begin{array}{l}\text { Boiling and } \\
\text { drying }\end{array}$ & 8.23 & 6.93 & 1.55 & 1.74 & 18.45 \\
\hline & $\begin{array}{l}\text { Boiling and pan } \\
\text { firing }\end{array}$ & 6.20 & 7.52 & 1.95 & 2.09 & 17.76 \\
\hline & $\begin{array}{l}\text { Steaming and } \\
\text { drying }\end{array}$ & 6.09 & 4.99 & 1.87 & 2.13 & 15.08 \\
\hline & $\begin{array}{l}\text { Steaming and pan } \\
\text { firing }\end{array}$ & 7.53 & 4.76 & 1.68 & 1.85 & 15.82 \\
\hline & $\begin{array}{l}\text { Mean } \\
\text { (fourth flush) }\end{array}$ & 7.07 & 6.56 & 1.81 & 1.78 & 17.2 \\
\hline
\end{tabular}

Epicatechin (EC), epigallocatechin (EGC), epicatechin-3- gallate (ECG), and epigallocatechin-3- gallate (EGCG). 
Table.3 $\mathrm{IC}_{50}$ values (mg) for 50\% DPPH scavenging of green tea of Assam

\begin{tabular}{|l|l|c|c|c|c|c|}
\hline Treatments & Commercial & $\begin{array}{c}\text { Boiling and } \\
\text { drying }\end{array}$ & $\begin{array}{c}\text { Boiling } \\
\text { and pan } \\
\text { firing }\end{array}$ & $\begin{array}{c}\text { Steaming } \\
\text { and drying }\end{array}$ & $\begin{array}{c}\text { Steaming } \\
\text { and pan } \\
\text { firing }\end{array}$ & Mean \\
\hline Flush 1 & 15.15 & 14.97 & 15.43 & 16.66 & 15.67 & 15.57 \\
\hline Flush 2 & 14.36 & 14.31 & 14.83 & 14.92 & 15.11 & 14.70 \\
\hline Flush 3 & 15.31 & 14.34 & 14.69 & 15.80 & 16.04 & 15.23 \\
\hline Flush 4 & 15.75 & 14.85 & 15.93 & 16.43 & 15.84 & 15.76 \\
\hline Mean & 15.14 & 14.62 & 15.22 & 15.95 & 15.66 & \\
\hline Factors & & flush & \multicolumn{2}{c|}{ Process } & flush x process \\
\hline CD $_{(\mathbf{0 . 0 5})}$ & & 0.25 & \multicolumn{2}{c|}{0.27} & \multicolumn{2}{c|}{0.55} \\
\hline
\end{tabular}

Table.4 Liquor characteristics (organoleptic evaluation) of green tea of Assam

\begin{tabular}{|l|c|c|c|c|c|c|}
\hline Treatments & Commercial & $\begin{array}{c}\text { Boiling and } \\
\text { drying }\end{array}$ & $\begin{array}{c}\text { Boiling and } \\
\text { pan frying }\end{array}$ & $\begin{array}{c}\text { Steaming } \\
\text { and } \\
\text { drying }\end{array}$ & $\begin{array}{c}\text { Steaming } \\
\text { and pan } \\
\text { frying }\end{array}$ & Mean \\
\hline Flush 1 & 5.0 & 4.5 & 4.5 & 4.5 & 5.0 & 4.70 \\
\hline Flush 2 & 6.0 & 5.0 & 5.5 & 5.5 & 5.0 & 5.40 \\
\hline Flush 3 & 6.5 & 7.0 & 7.0 & 6.5 & 6.0 & 6.60 \\
\hline Flush 4 & 6.0 & 6.0 & 5.5 & 5.5 & 5.0 & 5.67 \\
\hline Mean & 5.87 & 5.6 & 5.6 & 5.5 & 5.25 & \\
\hline
\end{tabular}

Fig.1 DPPH free radical scavenging activity $(\%)$ of green tea of second flush processed through commercial method

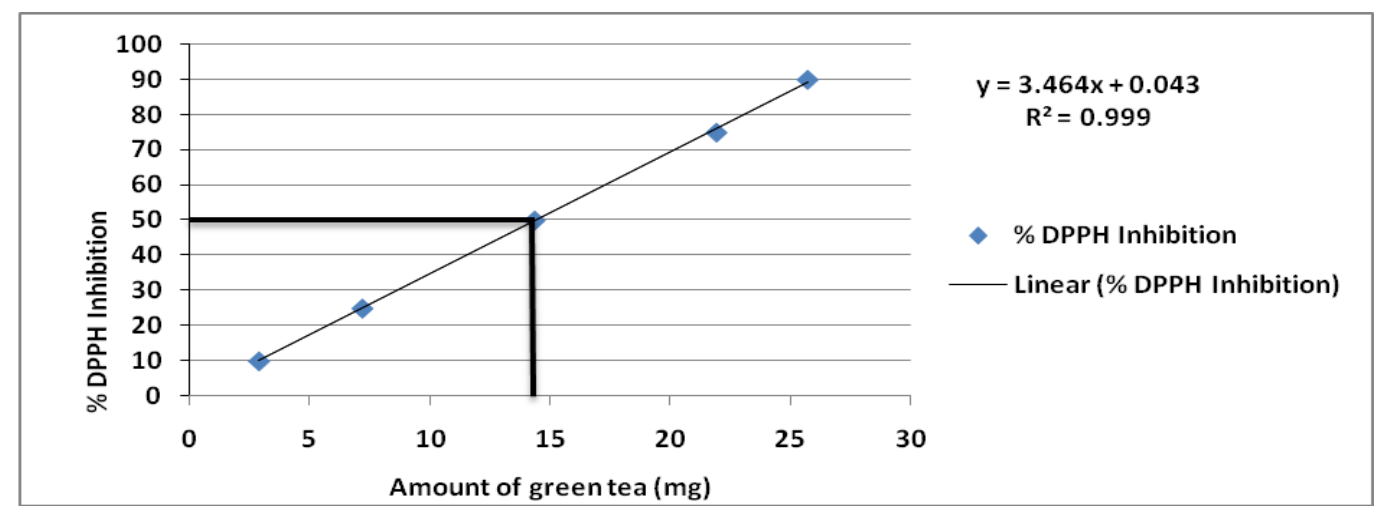

For commercially made green tea, the highest $(8.87 \%)$ and the lowest $(6.78 \%)$ EGCG content was observed during the first and the third flush, respectively. Among traditional methods, the highest $(9.71 \%)$ EGCG content was observed for green tea of first flush manufactured through boiling and drying and the lowest EGCG content (6.03\%) was observed for green tea of third flush processed through steaming and pan firing.

For commercially made green tea, the highest $(1.56 \%)$ and the lowest $(1.05 \%)$ ECG content was observed during the first and the third 
flush, respectively. The highest $(2.22 \%)$ ECG content was observed for green tea of first flush manufactured through boiling and pan firing.

In the present study in most of the samples, among the different catechins, the order of their content in the green tea were observed to be EGCG >EGC > EC> ECG. These results were in agreement with the earlier observation of Nakabayashi (1991) and Yamannotu et al., (1997) that the catechins decreased in the order of EGCG, EGC, ECG. The levels of EGCG, the main catechin gallates in tea flushes, were found to be higher in the leaves, harvested in warmer months. The amount of individual catechins in fresh tea leaves was higher in summer than in spring, as the growth rate and metabolic activities of the leaves were higher in summer (Caffin et al., 2005; Raveendran et al., 2003; Lin et al., 1996)

The $\mathrm{IC}_{50}$ values for $50 \%$ DPPH scavenging by green tea of Assam are presented at table 3. The antioxidant activity as expressed in terms of percent DPPH scavenging is presented in Figure 1 (only for sample made through commercial process during second flush). The lowest $\mathrm{IC}_{50}$ value of $14.31 \mathrm{mg}$ (the highest antioxidant activity) was observed for green tea of second flush processed through boiling and drying followed by sample manufactured by same method of third flush $(14.34 \mathrm{mg})$. The highest $(16.66 \mathrm{mg}) \mathrm{IC}_{50}$ value was observed for green tea of first flush processed through steaming and drying. The present findings for $\mathrm{IC}_{50}$ values was found to be comparable with those $(15.10 \mathrm{mg}$ and $11.31 \mathrm{mg})$ reported by, Yashin et al., (2011), Obaidi and Sahib (2015), respectively. The least $\mathrm{IC}_{50}$ values observed in second flush might be due to higher content of polyphenol during summer months. It was reported (Neog et al., 2018; Neog et al., 2020) that the total phenol (36.34 $\%)$ and ascorbic acid content $(16.49 \mathrm{mg} / 100 \mathrm{~g})$ were at their peak during second flush. In the present findings too, the total catechin $(20.80$ $\%$ ) was found to be maximum during second flush (summer) (Table 4).

For commercially made green tea, the highest (6.5) and the lowest (5) liquor characteristics were observed during the third and the first flush, respectively. For traditionally made green tea, the highest (7.00) liquor characteristics was observed for green tea manufactured through boiling and drying and boiling and pan firing of third flush. The lowest liquor characteristics (4.5) was observed for green tea of first flush processed through boiling and drying, boiling and pan firing and steaming and drying.

In conclusion it can be stated that considering sensory quality, higher total catechin content, lower caffeine content and $\mathrm{IC}_{50}$ value, the traditional method of boiling and drying appears to be better among all these methods, including commercial method of green tea manufacture. Similarly, considering the same qualities, the second flush is identified to be better for green tea making.

\section{References}

Astill C, Birch MR, Dacombe C, Humphrey PG, Martin PT (2001) Factors Affecting the Caffeine and Polyphenol Contents of Black and Green Tea Infusions. J Agr Food Chem., 49: 5340-5347.

Barua DN (1964) Selection of Vegetative Clone. Two and a Bud 11: 32-38.

Baruah S, Bordoloi AK, Gogoi RC, Gogoi MK, Hazarika M (2012) An integrated approach to the extraction of natural tea color, flavor and evaluation of antioxidant properties of tea. Two and a Bud 59(2): 126- 129.

Caffin N, D'Arcy B, Jiang Y, Shi J, Singanusong R (2005) Seasonal Variations of Phenolic Compounds in 
Australian-Grown Tea (Camellia sinensis). J Agric Food Chem 53: 64776483.

Chaudhury M, Bhawani S, Fong SS, Mohamad I (2010) Spectrophotometric analysis of caffeine. International $\mathbf{J}$ analytical chem.

Chen H, Zhang M, Qu Z, Xie B (2008) Antioxidant activities of different fractions of polysaccharide conjugates from green tea (Camellia sinensis). Food Chem 106(2): 559-563.

Duncan DB (1955) Multiple range and multible F tests. Biometrics 11(1):1-42.

Farhosh Y, Ikeda A, Maruyama K, Aoki N, Okubo T, Iso H (2007) Randomized controlled trial for an effect of green tea-extract powder supplementation on glucose abnormalities. Eur J Clin Nutr 23: 134-165.

Hara Y, Luo SJ, Wickremasinghe RL, Yamanishi T (1995) Special Issue on Tea. Food Rev Int 11: 371-545.

Harlan V, Musa A, Yakasai I (2015) Spectrophotometric method for determination of catechins in green tea and herbal formulations. Nig Journ Pharm. Sci 16(1): 25-30.

Higdon JV, Frei B (2005) Tea Catechins and Polyphenols: Health Effects, Metabolism, and Antioxidant Functions. Critical Reviews in Food Science and Nutrition 43(1): 89-143.

Khalid A, Ahmad S, Parveen N, Babar A, Lodhi RA, Rameez, Naseer F (2016) Determination of caffeine in soft and energy drinks available in market by using uv/visible spectrophotometer. Bull. Env Pharmacol Life sci 5: 14-20.

Lee LJ, Lee SH (2008) Extraction behavior of caffeine and EGCG from green and black tea. Biotechnology and Bioprocess Engg 13: 646-649.

Leenen R, Roodenburg AJC, Tijburg LBM, Wiseman SA (2000) A single dose of tea with or without milk increases plasma antioxidant activity in humans. European J Clinical Nutrition 54(1): 8792.

Leung LK, Su YL, Chen RY, Zhang ZH, Huang Y, Chen ZY (2001) Theaflavins in black tea and catechins in green tea are equally effective antioxidants. J Nutrition 131(9): 2248-2251.

Lin T, Chi Y (1995) Experimental study on polyphenol anti-plaque effect in human. Zhonghua Kou Qiang Yi Xue Za Zhi 35(5): 383-421.

Lok HC, Kit KM, Tung CK, Ho TS (2014) Chemical test for caffeine. Christian Alliance S C Chen Memorial College. Hong Kong.

Molyneux P (2004) The use of stable radical Diphenylpicrylhydrazyl (DPPH) for estimating antioxidant activity. Songklanakarin J of Sci. and technology 26(2): 211-219.

Nakabayashi O (1991) Chlorophyllase of Tea Leaves, II, Seasonal Changes of a Soluble Chlorophyllase. Shokubutsugaku Zasshi 82(976): 3926-3943.

Neog M, Das P, Saikia GK, Sarmah TC, Das Bora D (2018) Documentation of processing methods and biochemical quality study of green tea manufactured by small tea growers of Assam, India. Bull Env Pharmacol Life Sci 7 (11): 5157.

Neog M, Das P(2020) Changes in phytochemicals during processing of green tea. Int J Curr Microbial App Sci 9(1): 414-425.

Obaidi RSS, Sahib DH (2015) Determination of antioxidants activity in tea extract American J Biochem 5(3): 4952.

Qylo M, Aliko V (2016) The toxic effect of chloroform stress exposure on the Mediterranean Green Crab (Carcinus aestuarii). Albanian J Agric Sci 15(4): 177-182. 
Rahman MM, Kalam MA, Salam MA, Rana MR (2013) Aged leaves effect on essential components in green and oolong tea. Int $\mathbf{J}$ Agril Res Innov and Tech 3 (2): 54-58.

Raveendran K, Botheju WS, Priyanthi SH, Jayasinghe L (2003) A rapid method to determine moisture content in green leaf, withered leaves and made tea using a microwave oven. Sri lankan J Tea sci 68(2): 44-48.

Tarka MS, Hurst WJ (1998) Introduction to the Chemistry, isolation, and biosynthesis of methylxanthines in caffeine. Spiller, G A Eds CRC Press: Boca Raton 9-16.

Tsuneki $\mathrm{H}$, Ishizuka $\mathrm{M}$, Terasawa $\mathrm{M}, \mathrm{Wu} \mathrm{JB}$, Sasaoka T, Kimura I (2004) Effect of green tea on blood glucose levels and serum proteomic patterns in diabetic $(\mathrm{db} / \mathrm{db})$ mice and on glucose metabolism in healthy humans. BMC Pharmacol 26: 4-18.

Ullah MR, Gogoi N, Baruah S (1987) A rapid method for extraction and spectrophotometric determination of caffeine in tea. Two and a bud 34: 5053.

Wanyika HN, Gatebe EG, Gitu LM, Ngumba EK，Maritim CW (2010) Determination of caffeine content of tea and instant coffee brands found in the Kenyan market. African J Food Sci 4(6): 353 358.

Williamson G, Manach C (2005) Bioavailability and bioefficacy of polyphenols in humans. II. Review of 93 intervention studies. Am J Clin Nutr 81: 243-255.

Williams RJ, Spencer JPE, Evans C (1996) Flavonoids and isoflavones (phytoestrogens): Absorption, Metabolism and bioactivity. Free radical biology and medicine 36 (7): 838-849.

Yamamoto A, Korczak J, Amarowicz R (1997) Tea polyphenols-their antioxidant properties and biological activity-a review. Polish $\mathbf{J}$ fd Nutrition Sci 14(3): 219.

Yashin A, Yash, Nemzer B (2011) Determination of antioxidant activity in tea extracts, and their total antioxidant content. American J Biomedical Sci 3(4): 322-335.

Zayadi RA, Rahim NA, Bakar FA (2016) Determination of flavonoid and caffeine content in black and oolong teas. $\mathrm{J}$ of science and technol 8(2): 18-24.

\section{How to cite this article:}

Madhusmita Neog and Priyanka Das 2020. Profile of Catechins, Caffeine and Antioxidant Activities of Green Tea of Assam. Int.J.Curr.Microbiol.App.Sci. 9(11): 3330-3339. doi: https://doi.org/10.20546/ijcmas.2020.911.398 